\title{
Construction and operation of the Manukau Sewerage Scheme, Auckland, New Zealand
}

by

\author{
C. C. Collom, B.Sc.(Eng.), M.I.C.E.
}

Mr H. D. Manning (Partner, Messrs J. D. and D. M. Watson) said that he should declare his interest in the scheme in that his firm had acted as London agents and had been concerned with vetting much of the plant, a fair proportion of which, he was glad to say, came from the United Kingdom.

77. The early paragraphs of the Paper showed clearly the very unusual range of load on the works and brought out the suitability of this type of plant, which had a very considerable buffering effect, and its adaptability.

78. In $\$ 9$ there was a reference to the coliform count on the bathing beaches, and this had been mentioned in the introduction. The figure of 100 parts per $100 \mathrm{ml}$ had been laid down in the early days and later this had been amended to 1000 , which was more or less in line with many Californian standards. The circumstances were such that it might be many years before any standards, having sound scientific basis, could be formulated, but it was of interest to note that in some of the coastal towns in Britain samples showed 50000 to 100000 compared with the standard laid down in the Paper of 1000 . Those figures were not uncommon.

79. The interceptor was described as semi-elliptical in cross-section and certain overall figures were given. He had formed the impression from a quick calculation that the velocities were rather slack in times of low flow such as holiday periods. Would the Author comment on this? In this context, in $\$ 24$ there was a reference to design being made on the basis of good velocities but with the avoidance of turbulence. What was meant by that?

80. He would have thought that the nature of the waste and the corrosive conditions in the sewers called for turbulent flow and he noticed that the Author referred to consideration being given to forced ventilation in some sewers as a result of experience. A little more information would be interesting on the actual velocities on which they were designed.

81. In $\$ 23$ some figures were given for approximate annual costs. He could not understand the distinction between the figure of $£ 1196000$ given in the first two lines of $\S 23$ and the figure at the bottom of the page of $£ 1051000$. What had struck him most had been the references to the trade waste charges which, according to his calculations, represented about $14 \%$ of the cost of the scheme, whereas earlier in the Paper the impression was given that the trade effluents represented $75 \%$ of the B.O.D. loading on the plant. This seemed to indicate that the ordinary domestic contributor was paying rather more than his share of the cost of the scheme.

82. In $\$ 28$ reference was made to infiltration into separate systems being rather higher than expected. This trouble appeared to be occurring in some new towns in the United Kingdom but it had subsequently been found not to be infiltration but seepage into open-ended sewers left by building contractors during construction in the development areas. He wondered whether this was part of the explantation.

83. In $\$ 29$ reference was made to water-hammer effects on pumping stations. Could the Author confirm that these problems had been largely associated with the design of non-return valves or were there other factors which influenced the situation?

"Proc. Instn civ. Engrs, vol. 27, April 1964, pp. 703-738. 
84. There was a reference in $\S 34$ to the ingenious and very neat form of control of the recirculation in the oxidation ponds. It seemed to him from the description that this was slightly inflexible and he wondered whether there were other overriding controls in case the designed automatic rates did not prove to be exactly what were wanted.

85. All were agreed that the use of oxidation ponds, on this scale and at the time the decision was taken, had been a bold and wise decision, amply justified by the striking improvement in conditions. Although this method was not normally applicable in Gt Britain, as the author had stated in his introduction, there were many possible applications in the developing countries overseas. The point which he wished to make was that at Auckland, as was very proper and to be expected in an installation and organization of this size, there was a highly trained and highly qualified staff of engineers, chemists and biologists available to the Board. He wondered whether the Author felt that the process essentially called for this highly sophisticated control. This was of great importance when one was contemplating the application of similar plants in areas where there was great difficulty in getting trained staff.

Mr C. B. Townend (Messrs Rofe and Raffety) said that the Institution had been looking forward to a Paper on the subject for a very long time. The Author had given a well-prepared account, with good photographs and diagrams, supplemented by excellent slides, which made the whole subject easy to understand. It was full of novel ideas, giving plenty of food for thought over a wide range of subject matter.

87. On the broad issues, as Mr Manning had implied, it appeared that the courageous decision to use oxidation ponds as a secondary purification process for a city the size of Auckland had been well-justified. The ingenious reclamation of 1400 acres of mud flats at quite small expense for the purpose of creating those ponds was only one of the many examples employed in the scheme of the harnessing of natural features to achieve the required result at minimum costs. The problems involved in many cases had been very considerable.

88. On British experience, the $£ 9$ million cost of the main sewers appeared to be high, working out at $£ 27$ per head of the present population; but this would be reduced to $£ 11.5$ if calculated on the ultimate population which would provide a sounder basis for assessment in this case as probably no more expenditure ever be needed in future years.

89. It would be interesting to know the relative level of construction costs in the two countries. Although there were obviously many good reasons for the Auckland cost being above normal, including such problems as the awkward layout caused by the harbour areas and by geological conditions which were most unusual, it would nevertheless be interesting to have a comparison. One unusual feature of the scheme was the multiplicity of pumping stations, totalling 21 , which must add considerably to the cost both of construction and of operation. Normally one would expect a single main sewer located at a low level beneath the ground to bring the whole flow to one pumping station near the purification plant. It was assumed that in the Auckland case, the presence of basalt at the lower levels had prevented this arrangement. Perhaps the Author would comment on this aspect.

90. The methods of construction of underwater sections and above-ground pipelines by long assemblies of prestressed concrete pipes, and by concrete-lined steel pipes in other places, were particularly interesting. The various siphons appeared to be satisfactorily maintained by flushing at intervals of the deposited material by backing up the flow and in other ways. Were these formed of single pipes of the same diameter as the sewer, or was any attempt made to ensure a velocity of $4 \mathrm{ft} / \mathrm{s}$ or so through the pipe at all times by sub-division of the siphon section into two or more pipes coming into action with increasing flows as required from time to time? Such arrangements had generally proved quite satisfactory in this country. 
91. A point mentioned by Mr Manning interested him very much. The Author had given some prominence to sulphide troubles, mainly caused by industrial waste. Apart from mentioning the measures taken to ensure a dense concrete, the Author stated that sewers had been designed to give good velocities but to avoid turbulence. What velocities had been used in the design?

92. The only clue which the Author gave, and which $\mathrm{Mr}$ Manning had not followed up, was in $\$ 15$, where the Orakei sewer was said to fall $45 \mathrm{ft}$ in 12 miles. That sewer was of 85 -in. dia. enlarging up to an equivalent section of 102 -in. dia. at the lower end. This would indicate a velocity about $4 \frac{1}{2}-5 \mathrm{ft} / \mathrm{s}$ when running full, which was very satisfactory. But it would be much lower at minimum dry weather flows for the smaller population of the early years when the velocity could be under $3 \mathrm{ft} / \mathrm{s}$, and therefore rather critical for strong sewage with a B.O.D. of 400 or more, where temperatures were likely to be high. Could the Author give some information on that point?

93. In most cases it was fairly well known that sulphide build-up could be prevented with sufficiently high velocity, and it would often be better to spend more on power for pumping to give better sewer gradients than to risk odour nuisance and the possibility of concrete attack.

94. On the question of the sewer capacities provided, the maximum flow accepted for the combined sewers was given as five times the dry weather flow. This was presumably a total rate of about 250 ghd, whereas for the separate sewers the allowance was four times 50 ghd or 200 ghd, which the Author reported as being exceeded in many cases due to infiltration. It was most interesting that this conclusion accorded generally with British practice. The general position here was a trend towards 250 ghd maximum whether for combined sewers after overflow of the excess volume or through separate sewers with no overflow at all.

95. Had the Author used the term 'infiltration' into the separate sewers in the ordinary sense relating to subsoil water which would be continuous during wet periods for some considerable weeks or months, or was he referring to unauthorized water coming from roofs or paved areas by surreptitious connexions, which was the more usual interpretation in this country?

96. The results of operation shown in Table 1 gave an average sewage flow received of $40 \mathrm{mgd}$, which was equivalent to over 100 ghd of the existing population. Why was this so much in excess of the dry weather flow figure of 50 ghd?

97. On the treatment side of the picture, the outstanding point was that of the B.O.D. loading from trade effluent which was three times that of the domestic flow. This gave a total human equivalent impurity load averaging 1 million people with a monthly maximum of 1200000 , which accounted for a good deal of the costs of the plant involved. The seasonal nature of the principal trade effluents would lead to great fluctuations being handled by the works. Mr Manning had mentioned the oxidation ponds with their enormous capacity acting as a buffer. Mr Townend had worked out that at $3 \mathrm{ft}$ deep, the capacity appeared to be equivalent to 20 days' storage of the dry-weather flow, and that represented a most robust arrangement to deal with this extremely awkward problem.

98. These great variations in conditions could be taken care of without any apparent effect. He doubted very much whether this would be so with any other type of plant. It was one great advantage of the oxidation ponds, the other great merit being the considerable reduction of pathogenic organisms and the restoration of bathing beaches to excellent conditions. The capital cost of the pond process was exeedingly low, being only about $£ 210 \mathrm{~s}$. per head on the present population. It did not seem to be clear whether the present pond would serve the ultimate population of 800000 , but if so, the cost would be only $£ 1$ per head.

99. For the rest of the plant, however, serving primary treatment and sludge dis-

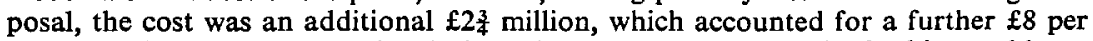
head, making over $£ 10$ per head altogether. On British standards this would not appear to be very low, in spite of the ingenious final disposal of the sludge in the 
volcanic crater, but the enormous load must be borne in mind, with its human equivalent of over 1 million; the cost per head on that basis would fall enormously. Presumably much of the preliminary plant would need to be duplicated for the ultimate conditions.

100. There were many other points on which he would like to comment, particularly on effluent quality and the use of oxidation ponds for procedures elsewhere, but he hoped that other speakers would raise them. He congratulated the Author on his excellent, most informative, and stimulating Paper.

Mr G. S. G. Goode (Partner, Messrs J. D. and D. M. Watson) said that he had had the good fortune to receive an invitation in 1955 to join the Board's staff in Auckland for three years to assist on the design of a purification plant and pumping stations. $\mathrm{He}$ had the great pleasure of working directly under $\mathrm{Mr}$ Collom and in close collaboration with the American consulting engineers.

102. Reference had been made to the controversy which raged in Auckland before the scheme was adopted. It needed considerable courage to propose the diversion of flow from the most densely populated areas of a very large city to another watershed for treatment some miles away. One would never know what the cost of the more conventional alternative would have been, although it was doubtful whether there would have been any saving.

103. The scheme allowed for the treatment of a very heavy load from trade wastes after dilution with domestic sewage. The treatment of those trade wastes without dilution would have been extremely difficult. The beautiful Waitemata Harbour was no longer subject to pollution from sewage, and the improvement in the Manukau Harbour, as reported by the Author, was very encouraging. These were substantial benefits from the scheme.

104. He was sorry that Mr Collom had not found a place for more information about the pumping stations, although some of them had been shown as slides during the introductory remarks. Many of the stations were of considerable size, as was inevitable in diverting so large a flow across the peninsula. The capacity of Orakei station was $52300 \mathrm{gal} / \mathrm{min}$, of St George $25000 \mathrm{gal} / \mathrm{min}$ and of Westfield 13000 $\mathrm{gal} / \mathrm{min}$. Excavation and concrete costs were very high and had justified the use of more elaborate plant to keep the stations as small as possible. Big ranges of flow had been covered by variable speed pumping using A.C. commutator and slip-ring type motors, and sump sizes had been reduced by matching pumping rates to sewage flows. Automatic control and simple arrangements for handling plant to a central workshop had been adopted to meet the high cost of operating, and maintenance staff.

105. The control system used at Orakei and in some other stations was a form of cascade control. The twin 42-in. dia. rising mains from the station were fitted with Venturi tubes and the measurement of pumping rates and of sump depths were transmitted pneumatically to the same controller. The controller tried to balance the measurements and when the water level varied from that desired for any paricular flow, it transmitted a signal to a series of pressure switches controlling the operation of the pumps. The set point of the controller was related linearly to the flow across the 61 -in. dia. incoming sewer.

106. The pumps in all stations had to be controlled in a way which would avoid surging in the small sumps as one or other of the larger pumps cut in or out. He would be interested to hear of the success which had been achieved. He would like to know whether the maintenance of variable-speed motors, control-gear instrumentation and other equipments had presented any particular difficulties.

107. On the purification plant he had time to refer only to features which were perhaps a little unusual in Britain. He remembered the manufacturers of the screening grinders expressing considerable doubt about the need for automatic reversal gear on these grinders and he would be interested to know whether, after experience, the Author felt that this facility had been worthwhile.

108. The spiral-flow aerated grit-channels, although widely used, were somewhat 
unusual in their form in Auckland. Grit removal was designed to take place in the first few feet of the spiral flow, pre-aeration tanks, having relatively large crosssectional areas. The forward velocity was very low and the spiral was flattened. One of the big advantages was that it needed only one small sump in each tank from which to pump the grit, which in this case was achieved with high-pressure water jet ejectors using a maximum of $75 \mathrm{gal} / \mathrm{min}$ of water at $60 \mathrm{lb} / \mathrm{sq}$. in. They were designed to deliver not less than $20 \mathrm{gal} / \mathrm{min}$ at $30 \mathrm{lb} / \mathrm{sq}$. in. discharge pressure. He would welcome an assurance that the grit was not deposited on the tank floors beyond the hoppers.

109. Concrete was very costly in New Zealand. It averaged about $f 12$ per cubic yard for the purification plant. It had therefore been decided not to follow strictly the terms of the code for water retaining structures of the Insitution of Civil Engineers in so far as it limited the steel and concrete stresses. Mild steel deformed bars had been used widely and the saving on steel costs had been appreciable. He had never been able to understand why these were used so widely in Australia, New Zealand, and America but not in Britain.

110. Manufacturers in Gt Britain had very little experience of vapour phase cooling of dual-fuel engines, and he wondered whether the Author could say whether the manufacturers had expressed any views on operating results. That form of cooling had led to the direct injection of steam for heating sludge. He now felt doubtful about the economics of the method, particularly in view of the very high cost of providing make-up water for the engines. Sludge was removed from sedimentation tanks by scrapers having timber flights and was pumped from the hoppers by air lift. He would be interested to know how the timber flights had stood up to the load in practice. There had been some doubts about this at the time. Had any use been made of the timer sequence control of airlift operation and of the grit ejectors? Sludge was pumped from a central sump by plunger pumps and was metered by magnetic flow meters. Had there been any opportunity to measure positively the accuracy of these meters?

111. The sludge digester covers were ballasted to provide gas pressures equivalent to 12 in. water column, which was fairly high, and gas storage was in high-pressure cylinders at $100 \mathrm{lb} / \mathrm{sq}$. in. gauge. His attention had been drawn recently to the possibility that those tanks might provide a maintenance problem and he would be grateful to hear the explanation.

112. The Author had dealt fairly fully with oxidation ponds and had shown some photographs of the building of the banks. But Mr Goode felt that the statement on page 725 needed some amplification. The Author remarked on the work of raising the banks with ordinary fill material across a tidal range of $17 \mathrm{ft}$ and said that this had been completed smoothly when the contractor had become accustomed to the difficulties. It was sometimes said that consulting engineers did not sympathize with contractors. On this occasion he had felt very sorry for them. Anyone who had watched children playing at building a sand castle to withstand the incoming tide would know the difficulties. The sight of the sea pouring over the closing weir at high tide had been quite awe-inspiring.

113. Conditions in Manukau Harbour from years of unrestricted effluent discharge from slaughterhouses had been dreadful, and it was good to hear that improvements were already apparent. Mr Collom's task in implementing this scheme after so much bitter controversy had imposed a very heavy strain on him. Despite this, he had always been kind and considerate and it had been a privilege to work for him and with such a fine team in New Zealand.

Mr E. F. Scott (formerly Chief Engineer, Drainage Board, Christchurch, N.Z.) said that it was a great pleasure for him, being on retiring leave from Christchurch Drainage Board, to be present. He paid tribute to $\mathrm{Mr}$ Collom and his staff for the successful completion of a difficult and pioneering project. $\mathrm{He}$ also thanked $\mathrm{Mr}$ Collom, his board and his staff, for their assistance to Christchurch Drainage Board 
over the years. They had permitted the survey panel, when in Auckland, to go to Christchurch and advise, and Christchurch had since followed Auckland's example in getting Dr Caldwell to design their own treatment plant, which was on similar lines but only half the size of Auckland. Christchurch was 600 miles nearer the South Pole and only about 8 hours' flight to the Antarctic so that although they had a similar plant there were slightly different problems.

115. Commenting on $\S 4$, he reinforced Mr Collom's remarks on the variation in flow by his experience with variations of domestic flow over the three weeks' holiday period following Christmas and New Year. From their recordings there was no doubt that the flow dropped over that three weeks' period when most people flocked to the seaside and mountains and deserted the city. A London newspaper had noted a report made by him a year or two ago stating that he had come down to a human level which was rare for an engineer. He had stated that during the Saturday afternoon of the Springbok Football Match between South Africa and New Zealand the domestic flow had almost entirely ceased for two hours and only infiltration rate flow had persisted.

116. Referring to $\S 46$, he said that it was disturbing to find that there were many faults in the machinery supplied from overseas and that there had been poor workmanship. There had been a number of examples, such as flanges not welded square with the axis of the pipe, which gave much trouble. There had even been fractured motor frames patched at the back where the 'repair' could not be seen. Working drawings had been inaccurate, inadequate, and often very late in arriving, which was a grave matter at the far end of the world.

117. Midges were dealt with in $\$ 54$. They had been a problem in Christchurch and his officers had been warned by $\mathrm{Mr}$ Collom and were benefiting from his experience. The first summer had been very difficult, but he was glad to say that the summer just ended had been relatively free of midge trouble. This was because the area of pond in the find sand-dune country had been reduced from 600 acres to a little over 250 acres, the balance being allowed to run dry.

118. After taking the full load of approximately 18 million gal/d for a whole year the first pond of 150 acres was now in a suitable condition in that midges did not develop. Many egg masses had been laid in the pond which not been sprayed during the past summer but very few larvae had developed.

119. The next two ponds in series occupied 30 and 70 acres respectively, and had been sprayed with only $66 \mathrm{lb}$ of D.D.T. during the 1963 summer. The small chemical dosage was due to the extreme care taken in defining the limit of the area requiring to be sprayed; it had been possible to spray from a motor launch on the pond.

120. Present thinking was that several conditions contributed to the non-development of the larvae. The first was the chemical toxicity, perhaps due to locally high concentrations of ammonia-sulphide on the fioor of the pond due to the heavier loading imposed. This indicated that the bottom of the pond was probably anaerobic. The second point was the distribution of particle sizes in the top layers of mud and the third was the hardness of the mud surface. The last two factors might be inter-related. The problem of midges was being actively studied by biologists on a three-year bursary programme.

121. It was shown in $\S 52$ that the ponds appeared to be capable of handling a higher load than originally provided for in the design. It had been found that the first quarter of the first pond did most of the work of B.O.D. removal but this was not so for the removal of pathogenic organisms.

122. Work was being done on the effects of these ponds in series on the bacterial counts which were higher than when all the ponds had been in use but the receiving waters were not adversely affected and the degree of pollution so far gave no rise for any concern. He thought that they could continue with much heavier loading of the ponds than had been originally intended.

123. Another feature in the variation of flow affecting the work had been due to 
power failures. With long-distance transmission lines and large hydro-electric power stations, there were occasional complete blackouts over a fairly large area, which caused all pumping in the whole of the metropolitan area to cease. With the restoration of power there was almost simultaneous starting of pumps. Originally that had caused the problem of 'hunting' in a plant almost entirely automatic in operation. There were only two operators on duty at a time in control of the whole plant.

124. Mr Collom had faced, as had Christchurch, a very big capital expenditure on a small population. Christchurch had spent about $f 8$ million on sewerage extensions with a population of 250000 . He was afraid that the extension and duplication of the main sewers and further works for the treatment of sewage would continue for many years. The people of New Zealand demanded a very high standard not only of health but of amenities and their saving grace was the fact that the population had almost 'exploded' and that the country was developing very quickly. It was hoped that before the loans were paid off in 30 years' time, the population would have doubled and the cost of the extra work would not be too great a burden.

Col. J. M. L. Bogle drew attention to $\S 9$ in which the Author referred to certain 'Waters Pollution Regulations, 1963', which required that the coliform bacteria content of the bathing waters should not consistently exceed 1000 per $100 \mathrm{ml}$. Mr Manning also had mentioned the point. Col. Bogle was interested in it because so far as he knew this was the only such Regulation which had ever been made. In the United States there were local regulations but he believed there was no general regulation covering the coliform content of outfall discharge. He knew of no such regulation for Gt Britain.

126. A Committee of the Ministry of Health dealing with the pollution of coastal waters in the neighbourhood of bathing beaches in Britain had said that in their opinion such a standard was neither necessary nor desirable. Many people did not agree with the view expressed by that committee. He would be interested to hear Mr Collom's opinion of how the Regulation had worked out in practice.

\section{The following contributions were received in writing:}

Mr J. P. Porter, having served as Chief Engineer to the Auckland Metropolitan Drainage Board from 1948-1954, and having resigned his appointment primarily because he was not prepared to accept responsibility either for capital cost or for the possible consequences of a scheme of the type described in the Paper, had originally intended to comment on some technical aspects of the Manakau Scheme, but had had to change his intention, as explained below.

128. In $\S \S 52-55$ of the Paper, reference was made to odours, midges, and mosquitoes originating within the site of the works. Early in 1964 the New Zealand Government, having taken note of complaints by local residents and by Manukau County Council on these matters, appointed a Commission of Inquiry to investigate the alleged nuisances and to recommend what action, if any, should be taken to deal with them. At its first sitting on 11 March, the Commission agreed to an adjournment of six months to enable the County Council to obtain detailed technical information and to prepare evidence. Having been asked to assist Counsel for the County in these matters, Mr Porter considered it would not be proper for him to submit technical comments on the scheme at this stage, pending resumption of the Inquiry. He therefore proposed to confine his remarks to the wide discrepancies between estimated and actual capital costs of the scheme; and to the opinions of two eminent Members of the Institution on incorporation of large scale oxidation ponds in the major sewerage scheme for Auckland (estimated 'ultimate' population $800000)$.

129. The estimated capital costs of the scheme, as set out in the Final Report (June 1956) of the engineers concerned, were as follows: for works required to year 
$1975, £ 7361100$; for all works (including first stage as above) to year 2000, $£ 9087600$. Late in 1963 revised costs and estimates were submitted to the Board as follows:

Actual cost of works to 6 September, 1963

$£ 13066449$

Estimated capital cost overall to year 1986 approx.

$£ 20000000$

130. These figures confirmed the opinion reached by $\mathrm{Mr}$ Porter following five years of detailed investigations on site and in the office, that they were far in excess of those estimated by the American engineers who had recommended adoption of the scheme.

131. On proposals for use of large-scale oxidation ponds at Auckland, in lieu of more orthodox methods of treatment, the following might be of interest to Members of the Institution.

132. Extensive evidence for and against an oxidation pond scheme to be located near the site of the present works was submitted to a Government-appointed Commission of Inquiry in 1949. The engineer member of that Commission was $\mathrm{Mr} \mathrm{T}$. B. Nicol, O.B.E., M.I.C.E., M.I.E.Aust., Engineer in Chief of the Metropolitan Water, Sewerage and Drainage Board, Sydney. The 1949 Commission strongly recommended against incorporation of oxidation ponds in the Board's major scheme of works, and in favour of a dual scheme, involving discharge to both harbours, following treatment by the activated sludge process.

133. The 'Panel' appointed by the Board which took office early in 1954, to advise whether the scheme approved by the 1949 Commission and commenced by letting of a $£ 2000000$ contract in 1953, should proceed or should be abandoned, included, in addition to the gentlemen mentioned in the paper, Mr John T. Calvert, M.I.C.E., a member of the firm of John Taylor and Sons, Westminster. In a Minority Report, dated May 1954, Mr Calvert stated among other things: 'I feel that it might be somewhat dangerous to translate results of the operation of oxidation ponds not greater than 100 acres in California to a scale many times that size in the entirely different climate of Auckland. I feel especially that the high flows which enter the combined sewers during periods of storm may have an unexpected effect on the operation of these ponds and I would recommend that experiments be carried out before any full scale ponds are put in hand.' Mr Calvert's Minority Report, which suggested, subject to certain conditions, continuance of the scheme of works commenced in 1953, is printed as an addendum to the Majority Report.

Mr D. Van Sickle (Head, Hydraulics Section, Turner \& Collie Consulting Engineers, Inc., Houston, Texas) observed that he was provided with a copy of the comprehensive report several years ago, through the courtesy of Mr Collom. At that time the magnitude of the project and the ingenuity and foresight of those attempting to solve the sewerage problem within the unique conditions imposed on them was a cause for much admiration, and additional data on the construction and operation of the proposed facilities were awaited with much interest. It had been a real pleasure, therefore, to read Mr Collom's very comprehensive Paper on the Manukau Scheme.

135. Obviously, Auckland's solution to the problem was not universally applicable and might well be unique, as $\mathrm{Mr}$ Collom had suggested in $\S 73$. However, the data presented merited detailed study and consideration where the possibility for similar treatment methods existed, and certainly the forthright manner in which $\mathrm{Mr}$ Collom and his associates had approached their problems was an example to public health engineers everywhere.

136. In order to evaluate the possible application of certain features of the Auckland scheme, in the consideration of alternative solutions to a current problem under study by Mr Van Sickle's firm, additional data on the following points would be helpful.

137. In $\$ 9$, a change in the general standard for bathing waters was noted which permitted up to 1000 coliform bacteria per $100 \mathrm{ml}$ as opposed to previous limits of 
only 100 per $100 \mathrm{ml}$. Mr Van Sickle had found it necessary to operate within the American Public Health Association's standards which were as listed below:

$\begin{array}{lcl}\text { Class } & \text { Average Coliform Index } & \text { Remarks } \\ \text { A } & 0-50 & \text { Good } \\ \text { B } & 51-500 & \text { Fair } \\ \text { C } & 501-1000 & \text { Doubtful } \\ \text { D } & \text { Over-1000 } & \text { Poor }\end{array}$

Was that essentially the same standard as was used by $\mathrm{Mr}$ Collom? Could he give any of the background information on the reasons for the change in New Zealand's standards, and the arguments for and against?

138. Also in $\$ 9$, the high cost of chlorine was mentioned. Because no additional mention was made of chlorination at the new treatment works, it was assumed that there was none. Was this assumption correct and, if so, what was the position of the Health Department or other regulatory agencies on the question?

139. In $\$ 20$, it was stated that all the larger pumping stations were automatically controlled. Did this mean that they were controlled from the treatment works central control board, or by a set of automatic controls in each station?

140. Could any additional data be given concerning the surge and water hammer problems mentioned in $\$ 29$ and the measures taken to correct them? Were surge studies made in the original design? What was the cost of the corrective measures taken?

141. Could additional data be given on the water jets used to move scum to the sedimentation tank inlet ( $\$ 32)$ ? What was the source of the water used?

142. The two different types of algal growth mentioned in $\$ 36$ and 59 appeared to occur under different loading conditions. Was information available to indicate at what proportion of the design loading the change in algal growth took place? Was there a marked change or could the two forms live together over some intermediate loading range? Had any objections been registered to the algal colouring of the water in the various recreational areas? How persistent was the colour?

143. Could a list be given of operating, maintenance and supervisory personnel required for the treatment works and the pumping stations if separate staffs were maintained?

144. Mr Collom would probably be unwilling to identify the manufacturers of the faulty equipment mentioned in $\$ 46$, and perhaps rightly so. Would he, however, be willing to identify the countries and the types of equipment involved?

145. Was the small suction dredge mentioned in $\$ 60$ used to remove mud and other harbour deposits to achieve the initial design depth of $3 \mathrm{ft}$ or was it used to maintain that design depth by pumping out new deposits of sewage solids?

146. What were the annual power requirements of the pumping stations compared with the total surplus power generated at the treatment works as described in $\S 64$ and Table 1 ? Was the pumping station power purchased at rates comparable to those received for sale of surplus power?

147. Had any difficulties been encountered with the dual-fuel engines, particularly insofar as extra maintenance or corrosion problems were concerned?

148. The operation of the Manukau sludge lagoons in a manner similar to the oxidation ponds was an interesting innovation and was further demonstration of the efforts of $\mathrm{Mr}$ Collom to improve operation of the works.

149. One could only agree with the statement in $\$ 73$ concerning the credit for the success of the enormous undertaking. Unquestionably, however, much additional credit was due to $\mathrm{Mr}$ Collom and his staff for their imaginative operation of an equally imaginative scheme. 
Mr A. W. Shilston (Consulting Engineer) observed that to appreciate fully the design themes and operational statistics included in such an outstanding Paper, the inclusion of certain basic desiderata would be helpful.

151. The design appeared to have had certain speculative aspects but in view of the savings in cost that could ensue they had been justified at the conception stage. Could an indication be given of what standards of purification the designers had set out to achieve and whether the results so far obtained broadly matched expectations?

152. Ambient temperatures were an important consideration but a more succinct appreciation of the significance of temperature would be gained if the range of actual sewage temperatures met could be quoted; those would depend to some extent on whether the Auckland water supply was derived from surface or underground sources.

153. To assess the probable condition of the sewage on arrival at the sewage purification works, could the individual drainage areas and populations served by the Western and Eastern Interceptors be stated, together with the distance from the Works of the most distant points now served by the respective drainage areas? Could a typical relationship in dry weather between maximum, average daily and minimum flows also be stated, both in respect of the two outfalls and the compounded works flow?

154. In regard to the future, the Paper indicated that the contributing population served by the Manukau Works would ultimately more than double. That implied presumably that areas more remote from the Works than at present would be connected to the system. What limiting distances and times of conveyance were involved and was conditioning of the sewage in the more remote areas before connexion to the main system deemed likely?

155. From $\$ 15$ and 17 , it appeared that the choice of sewer was related to the type of ground likely to be met. But was that so? Why were circular and egg-shaped sewers deemed to be equally suitable for construction in tunnel in sandstone? And why was the horse-shoe section particularly appropriate to clay areas? Was it in fact considered that the egg-shaped sewer had certain hydraulic advantages? $\mathrm{Mr}$ Shilston asked that question because in Gt Britain, the egg-shaped sewer was now very rarely used other than for some very particular reason. Perhaps the Author would enlarge on that section of the Paper.

156. Mr Shilston was interested in the reference in $\S 28$ to standards of sewer reticulation and house drainage. He thought it was fair to say that in Gt Britain mortar joints in spigot and socket sewer pipes were used less and less frequently but that did not yet appear to be the case in new house drainage work. As the bulk of infiltration came from house connexions that perhaps was to be regretted. Fairly recently he had heard a spokesman of the glazed vitrified clay manufacturing interests say that in New Zealand very extensive use was now made of pipes with pre-formed joints in house drainage. Was that Mr Collom's experience in the Auckland area?

157. Reference was made in $\S 31$ to the method of screening of sewage adopted. Had any views yet been formed whether the effects of returning disintegrated screenings to the main flow were such as to warrant consideration being given to their outright removal from the flow?

158. Mr Shilston was very interested in the reference to pre-aeration and its seeming axiomatic link with grit removal. If pre-aeration were a useful feature in a sewage purification works to mitigate the effects of septicity, then he would have thought that its use at Manukau was appropriate. In Gt Britain pre-aeration was viewed with mixed feelings and one heard of the scum problems that were brought about as a result of its adoption. Would it be true to say that the position at Auckland was as follows? Having decided to proceed with pre-aeration, to deal with septicity, no question arose of adopting a method of grit removal other than that of spiral flow air diffusion within the pre-aeration tanks. In Gt Britain the problems of pre-aeration and grit removal tended to be viewed as two separate issues but that was perhaps because spiral flow grit channels were still comparatively a new procedure.

159. The reference to operational staff in $\$ 41$ prompted Mr Shilston to ask how 
many day shift workers, including those engaged on pond and lagoon conservation, were necessary to allow the works to be run by three men during the remaining shifts. Could the board break-down of the staff organization at the works be given?

160. Although engineers were always mindful of the need to achieve maximum economy in capital expenditure, in their employers' interest, Mr Shilston had reflected, from time to time, on the need for more standardization in the selection of mechanical equipment manufacturers. The case might be made fairly readily, for example, for one manufacturer of instrumentation. In $\S 46$ the Author referred to the purchase of machinery from several countries. Had the diversity of electrical and mechanical plant resulted in any operational problems for that reason? Would the Author consider, for example, that standardization of electric motors was desirable?

161. On the subject of operating experience with mechanical equipment, could an indication be given of the Drainage Board's latest thinking on the most suitable form of seal for use on sewage and sludge pumps and electrical sump depth controllers for use in automatic pumping stations.

162. Could some remarks be made regarding the choice of depth in oxidation lagoons, having regard to such performance data as was now available at Auckland? It was not clear from $\S 60$ whether it was considered the need for periodical removal of sludge might arise. Presumably the draining down of ponds was not contemplated but perhaps the Author would confirm that.

163. Regarding the operation of the sludge lagoons, up to $50 \%$ of the digested sludge would be inorganic material. The balance would be organic matter resistant to biological degration. The reference in $\S 68$ to the solubilization of the sludge was perhaps surprising. Mr Shilston was subject to correction, but he understood that complete solubilization of seawage-derived organic matter was difficult to achieve by microbiological agencies. To appear to have solved the ever-present sludge problem, so readily, permitted a measure of scepticism! He would be glad to be proven wrong, but might not the suspended solids content of the liquors displaced by the daily load of sludge and overflowed, presumably to the oxidation ponds, be fairly high, thereby accounting for much of the residual organic matter, if a gradual build-up on the floors of the lagoons did not take place?

164. In considering the risks of infection arising from waters used for recreational purposes, with the detection of the presence of the indicator organisms, were both quantitative and qualitative bacteriological and virological checks carried out?

165. $\$ 50$ was very revealing. To bring the last two sentences into sharper relief, could the typical salinity of the water in Manukau Harbour be stated together with the temperature of the sea associated with photo-synthetic activity? Was that activity influenced by the presence in the water of nutrients of sewage derivation.

166. Mr Shilston, in conclusion, noted that there did not appear to be any reference in the Paper to the use of civil engineering contractors on the scheme. Were the works carried out by direct administration? If not, it would be instructive to earn whether either the measure and value type of contract under general conditions similar to those of the Institution, or the target type of cost plus incentive contract or the lump sum contract, without quantities, in the American style, was adopted. Were the treatment works built in several phased contracts or under one omnibus contract and were the various plant contracts treated as principal, or nominated subcontracts?

Mr J. Stebbings (Lecturer in Civil Engineering, University of Manchester) wrote that one seldom had the satisfaction of reading about such large-scale combined sewerage and purification works, executed in a short period of time, and designed to deal with a considerable increase in population. All too often those basic public health necessities were provided in a piecemeal manner or even lagged behind the development. The Paper was particularly interesting because it described methods of purification quite different from those traditional in Gt Britain. Not only were 
the oxidation ponds unusual but the capacity and flexibility of the recirculation system seemed to be an important factor in the design.

168. No doubt the climate of Auckland led to the choice of oxidation ponds and it would be interesting to have the Author's views on the conditions necessary for their successful operation, particularly with regard to minimum temperature.

169. The Author was to be congratulated on his bold and apparently successful experiment in the introduction of pond water to the sludge lagoon. Was it possible to carry this process a stage further? If sludge could be disposed of in this way, then why bother with sedimentation and digestion? Had the Author considered the treatment of crude sewage in a similar manner? The loss of gas production might not make the process economical in such a case but a successful experiment with controlled mixing with effluent would be an important development in sewage purification. A multi-stage process with recirculation at each stage might be the answer.

170. The Author deserved sympathy in his troubles with machinery. That kind of thing seemed to be on the increase and Mr Stebbings had suffered similarly to an extent which would have seemed impossible before the experience. There was little that could be done on the site and civil engineers should perhaps take a second look at their specifications to ensure that adequate redress could be obtained.

171. It was interesting to read the Author's remarks ( $\$ 28$ ) on flows in excess of 4 d.w.f. due to 'infiltration'. It was probably a common experience, and, with old sewerage systems, the trouble was practically impossible to eradicate due to difficulty in tracing the points of entry of water and the cost of rectification. Some research was needed, however, on the construction of sewers and the workmanship, neither of which had changed much in the last fifty years.

Mr E. W. Lee mentioned the difficulty, noted in $\$ 50$, of giving accurate performance details of plant operation. It appeared that the normally accepted parameters of B.O.D. and suspended solids removal were somewhat clouded by the presence of algae and possibly even by plankton in test samples. The Author reported average effluent B.O.D. of 40 p.p.m. with high of 60 p.p.m. The apparent oxygen demands of pond effluent reported were presumably made by the standard 5-day B.O.D. dilution test. These demands reflected not only the bacterial oxygen consumption but also the respiratory activities of algae within test bottles. The oxygen demand therefore could be expected to be higher than that normally expected from secondary treatment plants of other types. However, oxidation pond effluent should not be considered inferior since the algae present in effluent were assets by virtue of their oxygen productive ability. If incubation bottles were exposed to light (natural or artificial), photosynthetic activity would further interfere with normal test results. This was noted by the Author in dissolved oxygen determinations of samples kept in light and dark, wherein supersaturated dissolved oxygen conditions (40 p.p.m.) were reported.

173. The Author had reported that the suspended solids tests of effluents were made after removal of non-settling living organisms. Removal was made presumably to obtain samples reflecting only sewage solids. In reality, the non-settling organisms were constituents of effluents. Their exclusion from test results would not give a true expression of total solids content.

174. Thus it was apparent that both the standard B.O.D. and suspended solids tests were influenced by the presence of algae. It was suggested that alternate test techniques should be employed to express the unique characteristics of pond effluent.

175. The Warburg manometric technique as described in 'Standard methods for examination of water and wastewater' (11th Ed., U.S.P.H.A.) could be employed for oxygen-demand tests. The Warburg technique would permit short term (hourly) oxygen demand determinations and progressive determinations up to periods of five 
days on the same sample. It was suggested that any one sample be tested in three forms:

(a) sample including algae, tested in complete darkness;

(b) sample including algae, tested under artificial light; and

(c) sample including algae with life inactivated by bringing sample up to boiling point for a very short time. Algae could also be inactivated by sonic devices which would ensure rupturing of cell walls thereby releasing cell fluids for biological decomposition.

176. It could be seen that sample (a) would provide data on total respiration of bacteria and algae. Sample $(b)$ would measure algae oxygen production when compared with sample $(a)$ and sample $(c)$ will provide a measure of oxygen demand of the total organic composition of waste. Sample $(c)$ could also be subjected to the standard dilution B.O.D. test to determine oxygen demand without interference by algae.

177. Regarding the suspended solids test, it was suggested that a laboratory centrifuge be employed to overcome the reluctance of algae to settle out. The first portion from bottom of a centrifuge tube would be composed principally of algae while the upper portion of supernatant would be composed of dissolved solids and fine colloidal sewage particles. The total solids determined from these two states thus would be expressive of effluent characteristic taking into consideration the algae content.

178. Since one of the major products of an oxidation pond was algae, the cell counts shown in Table 5 were indicators of algae population. Some algae sizes varied not only between species but also within each species, the cell count alone was not the only indicator of algae activity. It could be suggested that the total chlorophyll content of samples should also be determined to provide a more expressive indication of algae life.

179. It was to be noted that 24 hours' composite samples of oxidation pond might not be sufficiently expressive of changing pond dynamics which were influenced by such environmental factors as light, temperature, wind action, etc. As an example, the $\mathrm{pH}$, alkalinity and dissolved oxygen of a pond would change throughout the day and night. It could be suggested that automatic determinations and chart recordings of $\mathrm{pH}$, alkalinity and dissolved oxygen would give a more vivid picture of pond dynamics.

180. The Author, the designers and the Drainage Board should be congratulated for bringing into operation a unique sewage plant of such great magnitude which employed the natural photosynthetic oxygenation of oxidation ponds for the stabilization of sewage and waste waters. It was hoped that the suggested test techniques would assist the operators in evaluating the characteristics of oxidation pond effluents, thereby providing greater understanding of the process. Other tests and techniques would no doubt be tried by operators. Together with the traditional analyses they would serve to present richer expressions of pond ecology.

Mr John R. Fitzmaurice (Consulting Civil and Sanitary Engineer, Auckland, New Zealand; formerly Designing Engineer (Special Works), Auckland Metropolitan Drainage Board) wrote that in an impressive manner the Author had covered very comprehensively a description of this large undertaking, and had given much design information as well as a full explanation of the operation and maintenance of the Treatment Plant.

182. A study of Fig. 12: Diagram of Recirculation, would enable one to enlarge on the Author's comment in $\$ 37$ that some of the sedimentation tanks might act as secondary tanks. The pond water returned to the sedimentation tanks, shown as 57 m.g.d. in Fig. 12, was introduced to the inlet channel of the tanks through butterfly gates at either end of the channel. By closing one gate all the return flow was introduced at one end of the bank of tanks and the end two or three tanks, depending on 
the flow, acted without a physical barrier as secondary tanks. The provision of two gates and two $2 \mathrm{ft} 6$-in. square penstocks shown diagrammatically in Fig. 12, permitting flow from the return channel to the influent channel, gave the hydraulic arrangement of the tanks a certain amount of flexibility, although smells due to concentrated loadings in the centre tanks stressed the requirement for greater flexibility in the hydraulic flow patterns available.

183. The Author had quoted predicted B.O.D. removals in terms of $1 \mathrm{~b} / \mathrm{d}$ in $\$ 37$ and had listed other data pertaining to B.O.D. removal in Tables 1 and 2. Table 2 showed a reduction in the monthly average value of B.O.D. for crude sewage and effluent as nearly $90 \%$. Predicted B.O.D. removals was quoted in $\$ 37$ for the trickling filters in terms of $\mathrm{lb} / \mathrm{d}$. The anticipated percentage removals for the different treatment processes were summarized as: sedimentation tanks $35 \%$, trickling filters $26 \%$, and oxidation ponds $33 \%$, totalling $94 \%$ which compared well with the statistical information in Table 2.

184. Steam for digester heating was infected into the raw sludge entering the digesters, ( $\$ 67)$, by an in-line steam injector and was not injected directly into the digesters themselves as could be inferred. Stable and uniform digester temperatures resulted therefrom and the active recirculation employed.

185. As noted in $\$ 32$, grit was removed from the preaeration tanks by water ejectors and sludge from the sedimentation tanks by air lifts. The latter devices gave rise to local smell problems, and it was to be noted that torque-flow pumps latterly were being used for those applications, which would remove that particular source of smell.

186. The Author referred to the pumping stations in the scheme in $\S 820$ and 29 . It was understandable that in a Paper of such scope the treatment of particular aspects would be inadequate. Only one instance of surge had occurred in the pumping stations in the scheme due to a power cut-out in circumstances which favoured the occurrence. No corrective measures were taken as stated but an overflow was provided to prevent flooding should the event recur. Damage due to water hammer had occurred to the rising mains of two stations equipped with automatically-closing valves and a third station with such valving experienced excessive rising main pressure without damage. Two stations equipped with reflux valves experienced similar trouble which was corrected with minor modifications to the valves.

The Author, in reply, thanked the contributors to the discussion. There had not been many of them, and perhaps he was a little disappointed in that, but he realized that oxidation ponds were a very specialized subject with little application in England. However, a large number of interesting points had been raised.

188. Mr Manning and Col. Bogle had spoken about the coliform count on bathing beaches. He agreed that there was at present no sound scientific basis on which a standard could be formulated. The tests should only be used as a guide and all other relevant circumstances must also be taken into account. There were numerous State regulations in America, but he agreed that there were probably no other national regulations as had been adopted in New Zealand. These were quite new and time would show how they worked in practice. It was interesting that the Pollution Advisory Council-of which he was a member-had formulated the regulations on the basis of standards of the receiving waters, but it had become clear that the Council could not disassociate itself entirely from the necessary standards for effluents entering the receiving waters.

189. Mr Manning and Mr Townend asked for more information on the actual velocities used in the sewers. This had been fully covered by Rowntree ${ }^{6}$ and he would only deal briefly with the matter. Mr Townend had correctly estimated that the velocities in the Eastern Interceptor were 4-5 ft/s when running full. The design had been based upon the work of Pomeroy ${ }^{16}$ and, for Auckland conditions, it had been calculated that the velocity required to prevent sulphide build-up should be 2.5-2.7 ft/s. He was not yet in a position to say whether or not the assumption had 
been correct, but the results of extensive maintenance observations would become available in a few years and would be published.

190. He was glad that Mr Manning had raised the question of turbulent flow as he had not made himself clear in the Paper. The flows were turbulent in the sense used by Mr Manning; but at manholes, junctions, and all similar places, they had carefully minimized any excessive turbulence which would cause the evolution of hydrogen sulphide. This was very necessary in any country where the temperature of the sewage could be high.

191. The authority was a local body carrying out a number of general functions, including the inspection of the reticulation of 18 other authorities. The larger figure given in $\$ 23$ included all expenditure, whereas the detailed figures at the bottom of p. 714 gave the separated cost of the operation and maintenance of the main sewers, pumping stations, and the treatment works.

192. Whereas the trade effluents represented a large proportion of the B.O.D. loading on the plant, the total cost of the sewerage system was much more affected by hydraulic considerations (particularly those brought about by peak rates of flow) than by pollutional load. The fair proportionate distribution of cost as between the domestic user and the manufacturer was calculated each year in arriving at the cost of treating the trade wastes, as had been detailed in another paper ${ }^{1}$ and this was the main basis of the charges, which were calculated with regard to $(a)$ volume, $(b)$ suspended solids, and (c) B.O.D. adjusted by a 'treatability' factor.

193. Several contributors referred to infiltration. The Author used the term in a general sense to mean all the flow in a separate sewer that could be avoided by perfect workmanship and supervision. One of the Board's difficulties was that the reticulation and house drainage were the direct responsibility of 18 other authorities, but experience had shown that co-operation could be obtained and that excessive infiltration could be avoided. They were coming to the conclusion that surreptitious connexions from roofs and paved areas were much more likely to be made in districts where there was an inadequate surface water drainage system and that such situations needed more attention. This was, of course, the responsibility of other authorities, but he hoped to get a general improvement.

194. Water hammer affects had been detailed by Fitzmaurice. ${ }^{\ominus}$ As suggested by $\mathrm{Mr}$ Manning, problems were associated with the design of non-return valves. For cone valves, they had asked for the closing time to be variable from 5 seconds to 90 seconds and had expected to obtain the necessary control within that range, but 90 seconds had proved to be inadequate in some cases. This had necessitated a change of mechanism, so that the first three-quarters of the closure could be done quickly and the remainder quite slowly. Another trouble had been reflux valves in vertical lines, which they tried to avoid. In some cases the flap gate was not held at a low enough angle to enable the reverse flow to actuate the valve quickly. External counterweighting had assisted in correcting such faults.

195. The form of control of the recirculation described in $\$ 34$ had been referred to by Mr Manning. The rate could also be varied by the number of pumps in use. Another recirculation system was also mentioned in $\$ 51$; whilst this was also partly automatic, there were butterfly gates which were used to set the main rate of return and the automatic control then served to maintain the rate approximately as required.

196. Mr Manning had referred to supervision and control and had asked what was required for oxidation ponds, mentioning that in Auckland a large and qualified staff was employed by the Board. This was essential for such a plant and many complex problems had been met. But for small oxidation ponds, say of 100 acres and less, not much supervision was necessary. Nevertheless, they must not be neglected. Recently, on his travels, he had visited a place where the ponds had been neglected and grass had grown out 20 or $30 \mathrm{ft}$ from the banks. This would be quite a problem to remove and would cause mosquito breeding and other troubles. Provided small ponds were not neglected, they did not require a high standard of chemical or engineering control. 
197. He particularly thanked $\mathrm{Mr}$ Townend for his kind remarks. It had been very encouraging to hear the pleasant comments about the works that had been described in the Paper. Mr Townend had asked about construction costs and $\mathrm{Mr}$ Goode had answered this question in part by giving the comparative cost of concrete. He could not easily provide any clear comparison between New Zealand and British costs. Wages were relatively high in New Zealand and the cost of all imported equipment had to include considerable freight and other charges. Contractors generally had too much work to do and there was sometimes a lack of specialized constructional plant. Some work had been done by direct labour, but there was overfull employment and so that also had its problems.

198. As Mr Townend surmised, the volcanic nature of the area and its broken terrain, which included such extensive lengths of coast-line, had dictated the use of the large number of pumping stations. It had been possible to reduce considerably the number originally contemplated, but he did not think it would have been practicable to lessen the total further, except by greatly increasing the capital outlay. The length of rising mains had been reduced to a minimum and sewer gradients had been designed to give good velocities even when this increased the pumping head.

199. Reference had been made to inverted siphons. Some of these were constructed with two separate pipes for carrying the flows. Others had three pipes. One in particular (\$17) had been built using a single pipe for constructional reasons. Conditions that resulted from this decision were now being studied and it seemed that it would have been preferable to have laid two pipes.

200. Mr Townend referred to the capacity provided in the sewers and to the average sewage flow of $40 \mathrm{mgd}$ which was equivalent to over $100 \mathrm{gal} / \mathrm{d}$ of the contributing population. Rainfall affected the average flow from the combined sewers and metering errors had also been detected and corrected. The similar figure for the past year was $30.86 \mathrm{mgd}$. This included trade wastes that would total about $5 \mathrm{mgd}$.

201. The oxidation ponds, in fact, averaged $5 \mathrm{ft} 3 \mathrm{in}$. in depth. The ponds would not be increased in area, due to geographical conditions, but the capacity of the works could be increased, so as to serve a population of 800000 , by increasing the number of filter-beds to six. Four more filter-beds would cost about $£ 350000$. He did not think that the ponds would take much more load than they did at present, unless they were assisted as had been suggested in $\S 61$. This was an interesting possibility and one that could be very economical. Another possibility was to make more use of Pond 4, the 'polishing' pond, and an alteration to the supply channels had just been completed, which would enable this to be done if required. This made the system more flexible. Such operation might affect the effluent standard, as indicated by Mr Scott's remarks on this subject, but this may not be unacceptable in view of the very high quality of the receiving waters at present.

202. He thanked Mr Goode for the additional information that he had given to supplement the Paper. Mr Goode had referred to the old controversy. The 'more conventional alternative' that he mentioned would have involved the construction of seven treatment works and even more pumping stations than those required for the proposals that were adopted. The town was expanding at a far greater rate than had been expected and anyone who now visited the seven proposed sites would undoubtedly be convinced of the merit of a solution that required a single treatment plant.

203. Mr Goode had asked a number of questions about the operation of the pumping stations. There had been no difficulty with surging during normal operation. This had happened only when a fault suddenly cut out a large pump. The variable-speed commutator motors had been trouble-free. There were cases of fairly rapid wear of brushes at first, but this was solved after experiments with different grades of carbon. There had been no special difficulties with control gear instrumentation, though it took a long time to adjust some of the equipment satisfactorily. Faults on pneumatic and hydraulic equipment occurred at an early stage 
through deterioration of the copper pipework. Copper had been replaced by plastic pipe in wet-wells.

204. He thought that the automatic reversal gear on the grinders could probably be omitted, but no comparative tests had been made with this feature not in use.

205. The grit removal system was satisfactory. The vapour phase cooling system was satisfactory now. There had been initial problems with little features of the engines that were not suited to the high temperatures. The cost of the direct injection of steam for heating sludge was being examined and a heat exchanger might be installed, so that the water could be recovered, rather than lost into the sludge digestion tanks. The change might not be warranted but, in a new system, he thought that the alternative would be preferable.

206. The timber flights had been satisfactory, though the whole cost of maintenance of the sludge collecting mechanisms was considerable. Timer sequence control of the airlift operation had not been satisfactory, but the same problems had not arisen in the case of the grit ejectors. The magnetic flow meters had been checked and were reasonably accurate. The sludge digestor covers and the highpressure storage tanks did not require excessive maintenance.

207. It had been pleasant to have Mr Scott present. They were old colleagues in New Zealand. He was also pleased to see Mr T. B. Nicol in the hall. They were old friends, as Mr Nicol had been a member of the 1949 Commission of Enquiry and knew much about Auckland's problems.

208. Mr Scott had commented on the variation of flow over the holidays and had mentioned similar experience at Christchurch. He had said that unfortunately Christchurch had had the same experience with manufactured plant-difficulties of bad workmanship and of getting correct drawings. Although much of the plant had come from the United Kingdom, one could not say that this was solely a United Kingdom fault, because it happened also with plant from Australia, America, and elsewhere. Nor was the problem due to lack of inspection; all the plant was inspected. It must be the fault of modern manufacturing methods. On numerous occasions they had altered manufacturers' plant, because it would not work in the way it was received. They had to do this themselves, since they were so far away from the factories. Afterwards the makers had agreed that the correct action had been taken and often all or some of the cost was repaid, which helped to maintain good relations. Nevertheless, there was much frustration. On one occasion they had been in difficulty because some plant would not operate satisfactorily. The agents had been very helpful and had cabled for more drawings. In a fortnight they had five sets of plans, none of which correctly portrayed the exact details of the machinery they were trying to alter! He had visited the manufacturer and had been impressed by the general efficiency of the organization. The particular machinery was not standard production and had had special problems.

209. He thanked Mr Scott for his comments about midges and noted the confirmation that ponds could be operated under conditions that made them unsuited as a habitat for midges. It was now thought that depth was one of the factors that was of significance.

210. Mr Scott had spoken about ponds with a high loading and the consequent effect upon reduction of the coliform counts. It would often be unnecessary to achieve the very high reductions in coliform counts that were possible by the use of oxidation ponds and, in the case of large pond systems, it might be preferable not to attempt to do so. The effect of the large populations of wild birds that inhabit such ponds should not be overlooked when assessing the reductions that are obtained. The Author now believed that lightly loaded ponds, designed to produce a maximum reduction of bacteria, needed particularly careful design and control, especially where the breeding of chironomid midges might be a problem.

211. Auckland was fortunate in that power failures of the type described by Mr Scott did not occur, because there were many transmission lines serving the area.

212. He hoped that he had sufficiently covered the discussion. What he had 
described in the Paper was the work of many people. He had referred to some in the Paper and he was particularly sorry that Dr Caldwell had not been able to be present. At one time it had been hoped that they could present a joint Paper or that Dr Caldwell would be able to come to London from San Francisco to take part in the discussion.

The Chairman said that he hoped that the Author would not feel disappointed about the discussion. If the number of contributors was not large, the standard had been very high-as high as that of the very interesting Paper.

214. Replying to the written contributions, the Author wrote that he much appreciated the interest that was shown. The written discussion brought the total number of questions that he had been asked to over sixty and, in order that his reply should not be of undue length, he would not answer some of these as fully as it appeared was desired. However, he would be pleased to add to his replies by correspondence, if necessary.

215. It was interesting that, in connexion with the Commission of Enquiry to which Mr Porter referred, a detailed and careful estimate of the cost of an alternative activated sludge plant had been prepared. This had shown that the annual cost of such a plant would be over $2 \frac{1}{2}$ times the cost of the works that were in operation.

216. Mr Porter was misinformed as to the extent of the works covered by the estimated and actual capital costs to which he referred and his figures were not comparative. It was correct that the works had cost much more than had been suggested by the original estimates that Mr Porter quoted. Paradoxically, he believed that the estimates had been carefully made and had not led to incorrect decisions. The lesson to be learned was that engineers should be most careful to ensure that preliminary estimates did not give rise to assumptions of reliability that were not warranted by the available data. This was particularly necessary when the works were to be carried out over a long period of time.

217. It was the Author's understanding that the 1949 Commission recommended against specific proposals, commenting that 'the evidence submitted by the league in support of the oxidation-lake proposals was, in the circumstances, somewhat meagre and unsatisfactory.... The Commission recommended a scheme that was later subject to most extensive modification. The 1954 proposals bore little resemblance to those that the Commission studied and, by that date, a pilot-plant oxidation pond had been constructed and had provided a certain amount of information not previously available.

218. There were, of course, overflows on the old combined sewers and the total flow in wet weather was limited to that which could be conveyed to the new system by the old outfall sewer. This had not caused any unexpected effect.

219. Mr Van Sickle commented further on coliform standards for bathing waters. The American Public Health Association's standards, as quoted, appeared to be more restrictive than the current New Zealand standard. He believed, though he did not have definite knowledge, that the change referred to had been due to a recognition of the circumstances to which Mr Manning had drawn attention in $\$ 78$. His personal opinion, and he hoped this would not appear presumptuous, was that there was not a sound scientific basis for the degree of accuracy apparently implied by the American standard.

220. Chlorination of the effluent was not practised, and since the condition of the receiving waters was acknowledged to be very high, there had been no suggestion that it should be employed.

221. All pumping stations were operated by individual automatic controls. In the event of failure of a control system, a message was automatically sent by means of the telephone system to the central control at the treatment works. Men were on standby duty and were called out on such occasions.

222. Mr Fitzmaurice's contribution dealt with surge and water hammer which had also been referred to in $\S 194$. The cost of corrective measures was very small. 
223. The water jets were spaced about $3 \mathrm{ft}$ apart along $1 \frac{1}{2}$-in. dia. header pipes and these were spaced approximately $15 \mathrm{ft}$ apart along the length of the sedimentation tanks. It was necessary to provide a walkway above each header and there were cross-sprays at the end of each tank to divert the scum to the collecting channels. Oxidation pond water was used.

224. He could not add to the information that he had given in $\$ \S 36$ and 59 . As the loading increased there was a marked change and careful pond management would ensure that the environment favoured desirable types of algae. In these circumstances there was no noticeable colouring of the receiving waters.

225. Mr Van Sickle and Mr Shilston asked for details of the treatment works and pumping stations staff. He would give a summary although this might be misleading, since the staff carried out a number of allied activities. For instance, the treatment works staff included those required for trades wastes control and the pumping station organization also covered the general workshops and maintenance of the whole vehicle fleet. The whole staff was as follows:

Treatment Works

Supervisory, laboratory, and office

Shift operations

Foreman, gardeners, and labourers

Workshops, instrument maintenance, painting, etc

19 Total 72

$\begin{array}{lrlll}\text { Pumping Stations } & & \\ \text { Supervisory and office } & 11 & \\ \text { Fitters } & 14 & \\ \text { Electricians } & 9 & \\ \text { Welders, machinists, and mechanics } & 7 & \\ \text { Labourers } & 22 & \text { Total } 63\end{array}$

226. Mr Van Sickle and Mr Shilston also commented on the depth of the oxidation ponds. The minimum depth of the ponds was now being increased to $4 \mathrm{ft}$, principally for reasons of midge control. There was no accumulation of deposited sewage solids and no dredging was carried out on that account. Draining of the ponds was not contemplated. It was now becoming recognized that most oxidation ponds were facultative and that separation of the aerobic and anaerobic phases was necessary. ${ }^{17}$ He thought there would be a tendency to construct deeper ponds than had been the practice previously.

227. The annual power requirement of 34 pumping stations was about $5250000 \mathrm{kWh}$. These pumping stations were scattered all over the district and the power charges included distribution costs. Surplus power was valued at generation rates and the two rates were not comparable.

228. Faulty equipment had been referred to in $\$ 208$. The operation of the dualfuel engines had been satisfactory, except as mentioned in $\S 205$.

229. Mr Shilston asked what standards of purification the designers had set out to achieve. These were set out at length in the relative report. ${ }^{3}$ Briefly the standards referred to the receiving waters and had been attained. The harbour was now in excellent condition.

230. Sewage temperatures reached a maximum of about $76^{\circ} \mathrm{F}$. Oxidation pond temperatures ranged from about $52^{\circ} \mathrm{F}$ to about $86^{\circ} \mathrm{F}$.

231. Strangely, the most distant point (measured along the sewers) was in the centre of the area served and this was about 23 miles. Most of the sewage travelled less than 15 miles. These distances were not deemed excessive and conditioning as suggested by $\mathrm{Mr}$ Shilston was not envisaged, though prechlorination at the works was under consideration.

232. The choice of circular and egg-shaped sewers in tunnel was dictated by the 
minimum height required for excavating equipment and the design flows. ${ }^{3}$ An eggshaped sewer was thus economical for certain flows, whereas higher or lower flows made circular sections, either cast-in-place or precast pipes, more suitable. The semi-elliptical section ${ }^{6}$ was suited to construction with the equipment that was available. A base of wide and flat cross-section was constructed first and this was desirable in the clay areas. The hydraulic characteristics of such a sewer are better than is often assumed and it must not be overlooked that the large water surface available at less than half flow assists in minimizing sulphide build-up.

233. Preformed joints for glazed vitrified clay pipes, as the Author understood the term, were not yet in use in New Zealand; but the regulations had for some years required flexible joints to be standard practice. These were generally made with rubber rings, but some flexible sleeve joints were also used. The joints used were not considered to be entirely satisfactory.

234. Returning distintegrated screenings to the sewage did not cause any difficulties. He concurred with Mr Shilston's comments upon pre-aeration and grit removal. It should be noted that such tanks can give rise to odours, if strong trade wastes are present, and that a recent decision has been made to cover and ventilate the tanks.

235. Instrumentation had been to a large extent obtained from one manufacturer. Provided that specifications for electrical and mechanical plant were detailed and precise, he did not think that any operational problems need arise from the acceptance in each case of the most suitable offer complying with the specification. Indeed, it would be difficult for a public authority to do otherwise.

236. Only water or grease sealing has been used and either is satisfactory provided it is recognized that the packing of such glands requires a high standard of workmanship. The larger pumps are usually water-sealed. With grease sealing, spring-loaded lubricators are preferred to grease pumps. A combined neck bush and lantern ring is not favoured and a ring of packing is used between the bush and the ring. Types of sump depth controllers must be varied to suit particular requirements. When compressed air is used in the control system, bubbler control is neat and satisfactory. ${ }^{9}$ For smaller stations electrode control is preferred. A system had been developed in which the electrodes were operated by an electrolyte of high conductivity controlled by sewage depth, but separated from the sewage by a flexible diaphragm. This required less maintenance than either simple or electronic electrode control.

237. The Author had possibly not made it sufficiently clear that, on the basis of the volume of digested sludge added daily, the capacity of the sludge lagoons was more than two years. In these circumstances, it was considered that much of the inorganic matter was also solubilized. Other matter was removed as algae and gasification caused a fürther loss. He could understand $\mathrm{Mr}$ Shilston's scepticism, but assured him that all that was required was sufficient area and the right climate?

238. Routine quantitative and qualitative bacteriological tests were carried out and some virological work was also done.

239. The salinity of the sea-water was 19600 p.p.m. of chloride and its temperature ranged from $53^{\circ} \mathrm{F}$ to about $74^{\circ} \mathrm{F}$. The sea-water used in the tests given in Table 4 was taken from an area remote from the outfall and it would be observed that this was photosynthetic.

240. The bulk of the construction was carried out by civil engineering contracts, using Bills of Quantities and Schedules of Prices, all work being remeasured at the end of each contract. Exclusive of the oxidation ponds and the preliminary earthworks, all work at the treatment plant was carried out under one construction contract. The works comprising the whole scheme had involved over 250 contracts. Generally plant was purchased and supplied to the principal contractor, but nominated sub-contractors had also been used.

241. Mr Stebbings enquired as to minimum temperatures with regard to oxidation ponds. These were used in America under conditions where the surface froze during winter. ${ }^{12}$ Some odour nuisance must be expected during the spring thaw. Crude 
sewage ponds were also widely used, but not for large installations. A variation of the methods that $\mathrm{Mr}$ Stebbings reviewed was to return digested sludge to the oxidation ponds. This appeared to have several advantages and was being investigated.

242. Mr Lee's contribution was both interesting and helpful. The Author agreed that conditions in oxidation ponds changed constantly throughout the day and night. The $\mathrm{pH}$ and dissolved oxygen also varied throughout the length and depth of a facultative pond, as had been clearly demonstrated. ${ }^{17}$

243. The Author thanked Mr Fitzmaurice for clarifying and amplifying several points, some of which had been raised during the discussion. He would like to make it clear that the reference to torque-flow pumps did not indicate that the airlifts had been replaced. Operational difficulties had been overcome, but he agreed that the alternative method was now being used in preference elsewhere.

244. He again wished to thank all who had taken part in the discussion for their interesting contributions and for their kind comments.

\section{REFERENCES}

16. R. Pomeroy and F. D. Bowlus. Progress report on sulfide control research. Sew. Wks J., vol. 18, no. 4, July 1946, pp. 597-640.

17. C. G. GolveKe, W. J. Oswald, and H. K. Lee. 'Increasing high rate pond loading by phase isolation.' Sanitary Engineering Research Laboratory, University of California, April 1962. 